\title{
Expression of mRNAs for DNA-methyltransferases and Histone Deacetylases in Granulosa Cells and Follicular Fluid of Women Undergoing in vitro Fertilization
}

\author{
Balint Farkas ( $\nabla$ dr.balint.farkas@gmail.com ) \\ University of Pecs School of Medicine \\ Sarolta Szalai \\ University of Pecs School of Medicine \\ Jozsef Bódis \\ University of Pecs School of Medicine \\ Timea Varjas \\ University of Pecs School of Medicine \\ Akos Varnagy \\ University of Pecs School of Medicine \\ Krisztina Godony \\ University of Pecs School of Medicine \\ Agnes Szenczi \\ University of Pecs School of Medicine \\ Endre Sulyok \\ University of Pecs School of Medicine
}

\section{Research Article}

Keywords: DNA-methyltransferases, follicular fluid, granulosa cells, histone deacetylases, in vitro fertilization, mRNA expression

Posted Date: March 2nd, 2022

DOI: https://doi.org/10.21203/rs.3.rs-1400621/v1

License: (c) (i) This work is licensed under a Creative Commons Attribution 4.0 International License. Read Full License 


\section{Abstract}

Background: Gene products involved in reproduction frequently undergo post-transcriptional modifications by DNA methylation and histone acetylation. The aim was to assess the predictive value of gene expression levels of DNA methyltransferases (DNMTs) and histone deacetylases (HDACs) in patients treated with in vitro fertilization (IVF). In a prospective, I clinical study 31 consecutive patients with male $(n=17)$ or female $(n=14)$ infertility diagnoses were enrolled. Granulosa cells (GCs) and follicular fluid (FF) were obtained at the oocytes retrieval during IVF. mRNA levels of DNMT1, DNMT3a, DNMT3b and HDAC5, HDAC6 were measured in GCs and FF by quantitative RT-PCR using ROCHE Lightcycler 480 . The outcome measures were the number of oocytes retrieved, mature oocytes and viable embryos, as well as chemical and clinical pregnancy.

Results: It was demonstrated that genes for DNMTs and HDACs could be detected in nearly equal amount in GC and FF, however, only the DNMT3a transcript in FF correlated with that in GC $(r=0.478, p<0.033)$. Moreover, FF DNMT3a was significantly higher in the pregnant $(\mathrm{N}=9)$ than in the nonpregnant $(\mathrm{N}=22)$ patients $(\mathrm{p}<0.016)$, and HDAC6 in GC was significantly related to the number of oocytes retrieved $(r=0.413, p<0.026)$, MII oocytes $(r=$ $0.383, p<0.040)$ and viable embryos $(r=0.413, p<0.025)$.

Conclusions: In our clinical setting the expression of mRNA for FF DNMT3a and for GC HDAC6 has the potential to assess IVF outcome.

\section{Background}

Epigenetic reprogramming during follicular maturation, oogenesis and pre-implantation embryo development has been shown to contribute to the reproductive outcome [1, 2]. Epigenetic modifications are achieved by four major mechanisms: a/ DNA methylation, b/ histone acetylation,c/ micro RNA expression and d/nucleosome positioning [3,4]. Currently, the impact of DNA-methylation and histone acetylation of maturing oocytes and early embryos on the reproductive performance is the subject of intensive research [5-11]. The pattern of DNA- methylation is mediated by the enzymes DNA methyltransferases that add methyl groups to DNA. Two types of DNA methylation have been documented; maintaining methylation is catalysed by DNMT1, while de novo methylation is performed by DNMT3a and DNMT3b[12, 13]. The acetylation status of histone proteins has also been claimed to play a critical role in transcriptional regulation and structural organization of chromatin and it has been proposed to be a potential biomarker for oocyte quality $[10,14]$. Histone acetylation occurs via the histone acetyltransferase enzyme (HAT) and deacetylation via the enzymes histone deacetylases (HDACs) [15]. NAD-dependent histone deacetylases comprise the Sirtuin family that confers cellular protection by regulating redox state, stress signalling, cell cycle and genome stability $[16,17]$. In this regard it is relevant to mention that our group recently reported that FF Sirtuin 6 and serum Sirtuin 1 and 6 were positively related to the number of mature oocytes and clinical pregnancy, respectively, when correction was made for confounders in women undergoing in vitro fertilization (IVF) [18].

In addition to histone acetylation, methylation of arginine residues of histone-and non-histone proteins are also thought to be an important regulator of cellular functions, in particular the structure and function of DNA. therefore, it has also been suggested to contribute to post-translational modifications [19-21]. With this notion in line significant negative association was found between FF I-arginine methylation products and the number of mature oocytes and viable embryos. Specifically, elevated levels of FF I-arginine, symmetric and asymmetric dimethylarginines and monomethyl arginine appeared to have an adverse influence on the reproductive performances in IVF patients [22].

On the basis of these observations the present study was designed to further explore the impact of gene expression profiles of the enzymes DNMT1, DNMT3a and DNMT3b, as well as HDAC5 and HDAC6 on the success of IVF program. The mRNA expression of these enzymes was determined in GC and GC-free FF obtained from IVF patients at the oocytes retrieval. Attempts were also made to find clinical correlates of the gene expression of these enzymes involved in mediating DNA methylation and histone deacetylation.

\section{Results}

Table II. shows the mRNA expression of DNMTs and HDACs in a GC and FF in all patients and separately, the pregnancy-positive and pregnancynegative groups. Each transcript could be detected in GC and FF samples without significant differences between samples from either source.

Patients who underwent successful IVF treatment and progressed to clinical pregnancy (9 patients) were compared with those who failed to become clinically pregnant (22 patients) no consistent changes could be detected between the two groups in their DNMT1, DNMT3a, DNMT3b or in HDAC5and HDAC6 expression in GC. However, DNMT3a expression level in FF proved to be significantly higher in the pregnant than in the nonpregnant group $(p<0.016)$. The mRNA expression of other enzymes studied in FF appeared to be similar irrespective of the IVF outcome.

To assess the possible contribution of mRNA expressions measured in GC to their respective levels in FF we examined the relationship between the corresponding parameters of GC and FF. Expect for DNMT3a transcript $(r=0.478, p<0.033)$ we failed to document associations between enzyme transcripts obtained simultaneously from GC and FF suggesting that the mRNAs of DNMT1, DNMT3b, HDAC5 and HDAC6 originate mostly from sources other than the GC.

Interestingly, there were significant positive relationships of DNMT1 to DNMT3b, DNMT3b to HDAC5 and HDAC5 to HDAC6, respectively, in GC. Furthermore, FF DNMT1 was significantly related to FF DNMT3a and to FF DNMT3b. FF DNMT3b was also related to FF HDAC5 and HDAC6, whereas FF HDAC5 was related to FF HDAC 6 (Table III.).

Page 2/10 
The effects of mRNA expressions on outcome measures in our patients were also evaluated. The number of oocytes, matured oocytes and viable embryos, as well as serum hCG levels on day 12 and clinical pregnancy were used as indices of outcome. Out of the gene expressions studied only the GC HDAC6 had significant impact on the number of oocytes $(r=0.404, p<0.030)$, matured oocytes $(r=0.383, p<0.040)$ and viable embryos $(r=$ $0.413, p<0.026)$. An attempt was also made to explore the influence of some common clinical/laboratory variables on the pattern of gene expression. No association was found between the age, BMI, number of previous IVF procedures, dose and duration of FSH stimulation, serum LH, progesterone andestradiol levels and the mRNA expression of any methyltransferases or deacetylases investigated. Since these clinical and laboratory parameters failed to affect significantly the gene expression patterns of DNMTs and HDACs they were not considered as confounders to be adjusted for.

\section{Discussion}

The present study showed that in women who underwent IVF the mRNA expression for DNMT1, DNMT3a, DNMT3band for HDAC5 and HDAC6 were present in both GC and FF and except for DNMT3a there were no significant differences between their expression levels in the two compartments. This suggests that the mRNAs of enzymes studied may also derive from sources other than GC. Concerning the association of gene expression with IVF outcome FF DNMT3a was significantly higher in the pregnant than in the non-pregnant group and the GC HDAC6 proved to be related to the number of oocytes, matured oocytes and viable embryos.

GCs are the major somatic cell compartments of the ovarian follicles and play a crucial role in achieving developmental competence of the maturing oocytes. Accordingly, stage-specific regulation of growing mouse oocytes by GC has been demonstrated [25] and the beneficial effects of GC coculture on in vitro oocyte maturation in murine and human models have been established [26, 27]. Experimental and clinical studies have been published to reveal the importance of GC in basic biological processes related to oocyte-quality and fertilization potential. In this regard investigations on telomere length and telomerase activity [28-30], identification of microRNAs [31, 32]and apoptosis markers [33, 34] are to be considered.

In a recent mRNA-seq and genome-wide DNA methylation study human ovarian GCs have been used to explore the role of genome and epigenome in the age-related decline in ovarian functions and female fertility. It was assumed that epigenetic alterations in these cells may reflect the interaction between the genome and environment. In support of this notion significant, non-random changes in transcriptome and DNA methylome features were demonstrated in human ovarian GCs as women age and their ovarian functions deteriorate [34] In this regard it is to be noted that ovarian aging involves not only decreased quality and quantity of oocytes but also those of the surrounding GCs [34].

In a most recent study Yang et al evaluated the genome-wide DNA methylation profile of human preimplantation embryos. In trophoectoderm biopsy samples from blastocytes they demonstrated negative correlations of genome-wide methylation levels to embryo quality and to maternal age confirming that increased level of DNA methylation may compromise embryo competence [35].

From clinical point of view it is to be stressed that there are marked differences in DNA methylation profiles of human oocytes and preimplantation embryos between in vitro- and in vivo conceived children which can be attributed to the assisted reproductive technologies (culture media, ovarian stimulation) rather than infertility [8, 36-39].

The histone acetylation is a prominent player of post-translational modifications. It is controlled by two opposing enzymes: histone acetyltransferases and histone deacetylases. In addition to histone, these latter enzymes (HDACs) catalyse deacetylation of other non-histone proteins. It has been shown that global histone deacetylation and activity of HDACs are essential for oocyte growth and survival [40]. Histone hyperacetylation induced by HDAC inhibitor trichostatin A during meiosis resulted in chromosome instability in pre-ovulatory and in vitro matured mammalian oocytes[41]. Importantly, GC from women with polycystic ovarian syndrome had widespread lysine acetylation of proteins and enhanced acetylation was associated with markedly reduced 2 pronuclear rates and the number of viable embryos during assisted reproduction [42]. With this observation in line in vitro maturation of oocytes from polycystic ovaries reduced the expression of HDAC1 in MII oocytes and two-cell embryos [43].To further support the involvement of histone acetylation in fertilization, meiosis-specific deacetylation [44] and increased acetylation levels during postovulatory aging [45] have been reported in mouse oocytes.

In our study the gene expression profiles of DNMTs and HDACs were evaluated in the easily accessible GCs. It was assumed that due to the close interactions of GCs with oocytes [46] we could get information about the quality and developmental potential of oocytes. Both cellular compartments release biologically active substances into the FF and FF is thought to mediate their cross-talk, therefore, mRNA expression levels in FF were also analysed. Except for DNMT3a, the gene expressions of other enzymes studied proved to be independent of their levels in GC that can be attributed to the possible contribution of transcripts derived from other follicular cells. Concerning the clinical relevance of our observations it should be emphasized that only the HDAC6 expression in GC was associated with the number of retrieved oocytes, matured oocytes and viable embryos and the FF levels of DNMT3a were significantly elevated in the pregnant vs non-pregnant group. These findings may be regarded as indicating limited predictive values of the transcripts measured, so one needs to be cautious when interpreting these laboratory data.

There have been reports on the interrelations of the multiple post-translational modifications during follicular development and oocyte growth [1, 4749]. The significant associations of mRNA expressions for DNMT and for HDAC we found in GC and FF are in agreement with these observations, however, further studies are warranted to confirm or exclude their causal relationships. 
In conclusion, mRNAs for DNMTs and for HDACs are expressed not only in GC but also in FF. The FF transcript may originate partly from GC, partly from other cell types of follicles. In our clinical settings mRNAs for DNMT3a and HDAC6have the potential to assess IVF outcome.

\section{Study limitations:}

Only a limited number of patients with heterogeneous infertility diagnosis were included in this study, therefore, diagnosis-specific subgroups could not be generated. Moreover, some contamination of FF samples with ovarian cells cannot be excluded that may interfere with the FF results. Largescale studies with patients of homogenous infertility diagnosis and with more meticulous separation of various cells are to be conducted to overcome these limitations.

\section{Conclusions}

FF of IVF women contains mRNAs for DNA-methyltransferases and histone deacetylases. The FF transcripts for DNMT3a are higher in pregnant than in non-pregnant patients, also transcripts for GC HDAC6 are associated with the number of oocyte and viable embryos, therefore expression level of FF DNMT3a and GC HDAC6 has predictive potential for IVF outcome.

\section{Methods \\ Patients}

This prospective, observational, clinical study was carried out between 1 September 2019 and 1 December 2019 in the Assisted Reproduction Unit, Department of Obstetrics and Gynecology, University of Pécs, Pécs, Hungary. The study comprised 31 consecutive patients who were indicated for fertility treatment. Eligible patients were recruited according to the data of the fertility consultation. Infertility was caused by male factors $(n=17)$ and female factors $(n=14)$ including tubal problems in 5 , endometriosis in 4 and unexplained in 5 cases. Enrolment of patients into the IVF procedure was approved by two independent physicians. Superovulation treatment, fertilization methods and embryo selection were performed according to standard protocols as described in our previous publication [23]. The major clinical and laboratory characteristics of the patients are summarized in Table I.

\section{Sample collection and preparations}

FF and GC were obtained by follicle puncture at oocyte retrieval. The collected FF was centrifuged for 10 minutes at $252 \times \mathrm{g}$ and the untreated supernatants were frozen and stored at $-80^{\circ} \mathrm{C}$ until analysis. For GC FF sediments were incubated in G-IVF ${ }^{\mathrm{TM}}$ solution for two hours. The mixture was subjected to mechanical and enzymatic treatment in G-Mops ${ }^{\mathrm{TM}}$ solution to cleanse the oocytes. At the end of this procedure the sediment contained GC concentrate. $0.5 \mathrm{ml}$ of this concentrate was injected into DNA/RNA LoBind Tube and $1 \mathrm{ml}$ ExtraZol Tri-reagent (EM30-200 NucleotestBio Budapest, Hungary) was added. This mixture was incubated in room temperature for 10 minutes, then stored at $-80^{\circ} \mathrm{C}$ for future analysis.

\section{Total RNA isolation and Q-RT-PCR}

$100 \mu \mathrm{l}$ of follicle fluid/400 $\mu \mathrm{l}$ of GC suspension was used for RNA isolation. Total cellular RNA was isolated using the ExtraZol Tri-reagent (EM30-200 NucleotestBio Budapest, Hungary) according to the manufacturer's standard procedures. The primary sequences of the internal control (housekeeping gene) hypoxanthine phosphoribosyltransferase 1 (HPRT1) were designed with Primer Express ${ }^{\text {TM }}$ Software (Applied Biosystems, Budapest, Hungary) and synthesized by Integrated DNA Technologies (Bio-Sciences, Budapest, Hungary). The primer sequences were as follows: DNMT1 forward, 5'- GGA GCA GGT GGA GAG TTA - 3' and reverse, 5'- GTA GAA TGC CTG ATG GTC TG -3'; DNMT3a forward, 5'- GCA GCG TCA CAC AGA AG -3' and reverse, 5'GGC GGT AGA ACT CAA AGA AG -3'; DNMT3b forward, 5'- GAA CGA CGT GAG GAA CAT C -3' and reverse, 5'- GGC CTG TAC CCT CAT ACA - 3'; HDAC5 forward, 5'- CAG CAC CAT CGG TTC ATA G -3' and reverse, 5'- CAG GGA GAG AGT GGG TAA G -3'; HDAC6 forward, 5'- GCC CAG GCT TCA GTT TC -3' and reverse, 5'- CCT CGC TCT CCT CTA CAT T -3'; HPRT1 forward, 5'- TGC TTC TCC TCA GCT TCA - 3' and reverse, 5'- CTC AGG AGGAGG AAG CC -3'. HPRT1 served as endogenous control.

The analysis of gene expression was performed by quantitative RT-PCR using a Roche LightCyclerß 480 Instrument I (Roche Molecular Systems, Inc. Budapest, Hungary). The thermo-program has been set by the KAPA SYBR® FAST One-Stepkit (KK4681, Merck, Hungary) protocol.

The resulting reaction mixture was measured: $10 \mu \mathrm{l} /$ cell KAPA SYBR FASTqPRC Master Mix, $0.4 \mu \mathrm{l} /$ cell KAPA RT Mix, $0.4 \mu \mathrm{l} /$ cell dUTP, $0.4 \mu \mathrm{l} / \mathrm{cell}$ primers, sterile bidest water, $5 \mu \mathrm{l} /$ cell template mRNA.

The PCR thermocycling conditions were as follows: Reverse transcription step at $42^{\circ} \mathrm{C}$ for 5 sec follows the enzyme inactivation $95^{\circ} \mathrm{C}$ for 3 sec. The PCR reactions were carried out for 40 cycles that comprised a denaturation step at $95^{\circ} \mathrm{C}$ for 10 sec, an annealing step at $58^{\circ} \mathrm{C}$ for 20 sec and an extension step at $72^{\circ} \mathrm{C}$ for $5 \mathrm{sec}$. The results were analysed by the relative quantification $\left(\Delta \Delta_{\mathrm{CT}}\right)$ method [24].

\section{Statistical analysis}

Statistical analysis was performed using IBM SPSS 24.0 software (IBM Corp., Armonk, NY, USA). Normality of data distribution was tested by the Kolmogorov-Smirnov test. To compare continuous variables Mann-Whitney U-test or Wilcoxon W-test were used. The association between two 
continuous variables was tested by using Spearman's or Pearson's correlation coefficients. The data are expressed as mean \pm SD, and $p<0.05$ was considered statistically significant.

\section{Abbreviations}

DNA Deoxyribonucleic Acid

RNA Ribonucleic Acid

mRNA Messenger Ribonucleic Acid

IVF In vitro Fertilization

DNMT Deoxyribonucleic Acid Methyltransferase

HDACS Histone Deacetylase

HAT Histone Acyltransferase

GC Granulosa Cell

FF Follicular Fluid

hCG Human Chorionic Gonadotropin

HPRT1 Phosphoribosyltranferase 1

\section{Declarations}

\section{Ethics approval and consent to participate}

The study was reviewed and approval by the Human Reproduction Committee of the Hungarian Medical Research Council (5273-2/2012 HER). Signed informed consent was obtained from all patients who participated in the study. The investigation conforms to the principles outlined in the Declaration of Helsinki.

\section{Availability of data and materials}

The dataset supporting the conclusions of this article is available from the corresponding author on reasonable request.

\section{Competing interests}

The authors state that there are no conflicts of interest regarding the publication of this article.

\section{Funding}

This work was supported by the Institutional Excellence Program (17886-4/2018/FEKUTSTRAT) and GINOP-2.3.2-15-2016-00021 ("The use of chiptechnology in increasing the effectiveness of human in vitro fertilization"). The funding sources did not have any role in the study design; in collection, analysis and interpretation of data, or in writing and submitting this manuscript.

\section{Authors' contributions}

All authors read and approved the final manuscript. SS, JB, ES and BF conceived, designed and managed the study, SS, JB, ES and AV contributed to the study conceptualization and provided critical editorial input to the interpretation of the data, TV, ASZ, and KG contributed in laboratory and statistical analysis, AV, ES and FB contributed to data collection, to the drafting and final editing of the manuscript.

\section{Acknowledgement}

The research was financed by the Thematic Excellence Program 2020 (Institutional Excellence Subprogram of the Ministry for Innovation and Technology) in Hungary, within the framework of the second thematic program of the University of Pecs and ELKH-PTE Human Reproduction 
Scientific Research Group, Pecs, Hungary and National Laboratory for Human Reproduction as part of the "Establishment of National Laboratories 2020 " program. The authors are grateful to the IVF patients for their participation in this study. The publication and the scientific results presented in this study were prepared also with the support of the Richter Gedeon Talentum Foundation established by Richter Gedeon Plc. (headquarters: 1103 Budapest, Gyömrői ut 19-21.) in concordance with the framework of the Richter Gedeon PhD Scholarship.

\section{References}

1. Bunkar N, Pathak N, Lohiya NK and Mishra PK: Epigenetics: A key paradigm in reproductive health. Clin Exp Reprod Med 43: 59-81, 2016.

2. Chamani IJ and Keefe DL: Epigenetics and Female Reproductive Aging.Front Endocrinol 10: 473, 2019.

3. Jaenisch R and Bird A: Epigenetic regulation of gene expression: how the genome integrates intrinsic and environmental signals.Nat Genet33 Suppl: 245-254, 2003.

4. Friedman $\mathrm{N}$ and Rando OJ: Epigenomics and the structure of the living genome.Genome Res25: 1482-1490, 2015.

5. Paulsen M and Ferguson-Smith AC: DNA methylation in genomic imprinting, development, and disease.J Pathol195: 97-110, 2001.

6. Huntriss J, Hinkins M, Oliver B,Harris SE, Beazley JC, Rutherford AJ, Gosden RG, Lanzendorf SE and Picton HM: Expression of mRNAs for DNA methyltransferases and methyl-CpG-binding proteins in the human female germ line, preimplantation embryos, and embryonic stem cells.Mol Reprod Dev67: 323-336, 2004.

7. Reik W: Stability and flexibility of epigenetic gene regulation in mammalian development.Nature447: 425-432, 2007.

8. Petrussa L, Van de Velde H and De Rycke M: Dynamic regulation of DNA methyltransferases in human oocytes and preimplantation embryos after assisted reproductive technologies.Mol Hum Reprod20: 861-874, 2014.

9. Imhof A and Wolffe AP: Transcription: gene control by targeted histone acetylation.Curr Biol8: R422-424, 1998.

10. Manosalva I and González A: Aging alters histone H4 acetylation and CDC2A in mouse germinal vesicle stage oocytes.Biol Reprod81: 1164-1171, 2009.

11. van den Berg IM, Eleveld C, van der Hoeven M,Birnie E, Steegers EAP, Galjaard R-J, Laven JSE and van Doorninck JH:Defective deacetylation of histone 4 K12 in human oocytes is associated with advanced maternal age and chromosome misalignment.Hum Reprod26: 1181-1190, 2011.

12. Bestor TH: The DNA methyltransferases of mammals.Hum Mol Genet9: 2395-2402, 2000.

13. Okano M, Bell DW, Haber DA and Li E: DNA methyltransferases Dnmt3a and Dnmt3b are essential for de novo methylation and mammalian development.Cell99: 247-257, 1999.

14. . Roth SY, Denu JM and Allis CD: Histone acetyltransferases.Annu Rev Biochem70: 81-120, 2001.

15. Akiyama T, Nagata M and Aoki F: Inadequate histone deacetylation during oocyte meiosis causes aneuploidy and embryo death in mice.Proc Natl Acad Sci U S A103: 7339-7344, 2006.

16. Satoh A, Stein L and Imai S: The role of mammalian sirtuins in the regulation of metabolism, aging, and longevity.Handb Exp Pharmacol206: 125-162, 2011.

17. Giblin W, Skinner ME and Lombard DB: Sirtuins: guardians of mammalian healthspan.Trends Genet 30: 271-286, 2014.

18. Bódis J, Sulyok E, KőszegiT, Gödöny K, Prémusz V and Várnagy Á: Serum and follicular fluid levels of Sirtuin 1, Sirtuin 6 and Resveratrol in women undergoing in vitro fertilization: an observational clinical study.J Int Med Res2018.

19. Zhang $Y$ and Reinberg D: Transcription regulation by histone methylation: interplay between different covalent modifications of the core histone tails.Genes Dev 15: 2343-2360, 2001.

20. Biggar KK and Li SS: Non-histone protein methylation as a regulator of cellular signalling and function.Nat Rev Mol Cell Biol 16: 5-17, 2015.

21. Rose NR and Klose RJ: Understanding the relationship between DNA methylation and histone lysine methylation.Biochim Biophys Acta 1839: 1362-1372, 2014.

22. Bodis J, Varnagy A, Sulyok E, Kovacs GL, Martens-Lobenhoffer J and Bode-Boger SM: Negative association of I-arginine methylation products with oocyte numbers.Hum Reprod25: 3095-3100, 2010.

23. Várnagy A, Bódis J, Kovács GL, Sulyok E, Rauh M and Rascher W: Metabolic hormones in follicular fluid in women undergoing in vitro fertilization.J Reprod Med58: 305-311, 2013.

24. Livak KJ and Schmittgen TD: Analysis of relative gene expression data using real-time quantitative PCR and the 2(-Delta Delta C(T)) Method.Methods25: 402-408, 2001.

25. Klinger FG and De Felici M: In vitro development of growing oocytes from fetal mouse oocytes: stage-specific regulation by stem cell factor and granulosa cells.Dev Biol 244: 8f5-95, 2002.

26. Boon CH, Tong GO, Ng SC. et al. Effects of granulosa co-culture on in vitro oocyte meiotic maturation within a putatively less competent murine model.Theirogenology 62:1066-1092, 2004.

27. Johnson JE, Higdon HL and Boone WR: Effect of human granulosa cell co-culture using standard culture media on the maturation and fertilization potential of immature human oocytes.Fertil Steril 90: 1674-1679, 2008. 
28. Chen H, Wang W, Mo Y,Ma Y, Ouyang N, Li R, Mai M, He Y, Bodombossou-Djobo MMA and Yang D: Women with high telomerase activity in luteinised granulosa cells have a higher pregnancy rate during in vitro fertilisation treatment.J Assist Reprod Genet28: 797-807, 2011.

29. Wang W, Chen H, Li R,Ouyang N, Chen J, Huang L, Mai M, Zhang N, Zhang Q and Yang D: Telomerase activity is more significant for predicting the outcome of IVF treatment than telomere length in granulosa cells.Reproduction147: 649-657, 2014.

30. Kosebent EG, Uysal F and Ozturk S: Telomere length and telomerase activity during folliculogenesis in mammals.J Reprod Dev64: 477-484, 2018.

31. Luo H, Han Y, Liu J and Zhang Y: Identification of microRNAs in granulosa cells from patients with different levels of ovarian reserve function and the potential regulatory function of miR-23a in granulosa cell apoptosis.Gene686: 250-260, 2019.

32. Zhang J, Xu Y, Liu H and Pan Z: MicroRNAs in ovarian follicular atresia and granulosa cell apoptosis.Reprod Biol Endocrinol 17: 9 , 2019.

33. Oosterhuis GJ, Michgelsen HW, Lambalk CB, Schoemaker J and Vermes I: Apoptotic cell death in human granulosa-lutein cells: a possible indicator of in vitro fertilization outcome.Fertil Steril70: 747-749, 1998.

34. Yu B, Russanova VR, Gravina S,Hartley S, Mullikin JC, Ignezweski A, Graham J, Segars JH, DeCherney AH and Howard BH: DNA methylome and transcriptome sequencing in human ovarian granulosa cells links age-related changes in gene expression to gene body methylation and 3 '-end GC density.Oncotarget6: 3627-3643, 2015.

35. Yang M, Tao X, Scott K, Zhan Y, ScottRT, Seli E: Evaluation of genome-wide DNA methylation profile of human embryos with different developmental competences.Human Reprod2021 https://doi.org/10.1093/humrep/deab074.

36. de Waal E and McCarrey J: Effects of exogenous endocrine stimulation on epigenetic programming of the female germline genome.Anim Reprod7: 154-154, 2018.

37. van Montfoort AP, Hanssen LL, de Sutter P, Viville S, Geraedts JP and de Boer P: Assisted reproduction treatment and epigenetic inheritance. Hum Reprod Update18: 171-197, 2012.

38. Denomme MM and Mann MR: Genomic imprints as a model for the analysis of epigenetic stability during assisted reproductive technologies.Reproduction144: 393-409, 2012.

39. Song S, Ghosh J, Mainigi M,Turan N, Weinerman R, Truongcao M, Coutifaris C and Sapienza C: DNA methylation differences between in vitroand in vivo-conceived children are associated with ART procedures rather than infertility.Clin Epigenetics7: 41, 2015.

40. Ma P, Pan H, Montgomery RL, Olson EN and Schultz RM: Compensatory functions of histone deacetylase 1 (HDAC1) and HDAC2 regulate transcription and apoptosis during mouse oocyte development.Proc Natl Acad Sci U S A109: E481-489, 2012.

41. Ikeda S, Tatemizo A, Iwamoto D,Taniguchi S, Hoshino Y, Amano T, Matsumoto K, Hosoi Y, Iritani A and Saeki K: Enhancement of histone acetylation by trichostatin A during in vitro fertilization of bovine oocytes affects cell number of the inner cell mass of the resulting blastocysts.Zygote17: 209-215, 2009.

42. Pei W, Min Z and Yu Y: Lysine Acetylation in Granulosa Cells of PCOS Women Regulated by Carbohydrate Metabolism.FASEBJ34: 1-1, 2020.

43. Wang N, Le F, Zhan QT, et al: Effects of In Vitro Maturation on Histone Acetylation in Metaphase II Oocytes and Early Cleavage Embryos.Obstet Gynecol Int 2010: 989278, 2010.

44. Kim JM, Liu H, Tazaki M, Nagata M and Aoki F: Changes in histone acetylation during mouse oocyte meiosis.J Cell Biol 162: $37-46,2003$.

45. Huang JC, Yan LY, Lei ZL,Miao Y-L, Shi L-H, Yang J-W, Wang Q, Ouyang Y-C, Sun Q-Y and Chen D-Y: Changes in histone acetylation during postovulatory aging of mouse oocyte.Biol Reprod77: 666-670, 2007.

46. Suganuma T and Workman JL: Signals and combinatorial functions of histone modifications.Annu Rev Biochem80: 473-499, 2011.

47. Wee G, Shim JJ, Koo DB, Chae JI, Lee KK and Han YM: Epigenetic alteration of the donor cells does not recapitulate the reprogramming of DNA methylation in cloned embryos.Reproduction134: 781-787, 2007.

48. Yang F, Baumann C, Viveiros MM and De La Fuente R: Histone hyperacetylation during meiosis interferes with large-scale chromatin remodeling, axial chromatid condensation and sister chromatid separation in the mammalian oocyte.Int J Dev Biol 56: 889-899, 2012.

49. Hara S, Takano T, Fujikawa T,Yamada M, Wakai T, Kono T and Obata Y: Forced expression of DNA methyltransferases during oocyte growth accelerates the establishment of methylation imprints but not functional genomic imprinting. Hum Mol Genet 23: 3853-3864, 2014.

\section{Tables}

\section{TABLE 1}

The major clinical and laboratory characteristics of IVF patients who progressed to chemical/clinical pregnancy and those who failed to become pregnant 


\begin{tabular}{|c|c|c|c|c|c|c|c|}
\hline \multirow{2}{*}{ Characteristic } & \multicolumn{2}{|l|}{$\begin{array}{l}\text { All } \\
\text { patients }\end{array}$} & \multicolumn{2}{|l|}{$\begin{array}{l}\text { Pregnancy } \\
\text { negative group }\end{array}$} & \multicolumn{2}{|l|}{$\begin{array}{l}\text { Pregnancy } \\
\text { positive group }\end{array}$} & \multirow{2}{*}{$\begin{array}{l}\text { Mann- } \\
\text { Whitney test } \\
\text { p-value }\end{array}$} \\
\hline & $(n=31)$ & & $(n=20)$ & & $(n=11)$ & & \\
\hline Age (y) & 35.00 & $\begin{array}{l}(29.00- \\
39.00)\end{array}$ & 37.50 & $\begin{array}{l}(31.00- \\
41.00)\end{array}$ & 32.00 & $(29.00-35.00)$ & 0.030 \\
\hline BMI $\left(\mathrm{kg} / \mathrm{m}^{2}\right)$ & 23.50 & $\begin{array}{l}(22.10- \\
24.60)\end{array}$ & 23.30 & $\begin{array}{l}(22.10- \\
24.18)\end{array}$ & 24.50 & $(22.10-26.80)$ & 0.273 \\
\hline $\begin{array}{l}\text { Female infertility, } n \\
(\%)\end{array}$ & 14 & $(45.16)$ & 9 & $(45.00)$ & 5 & $(45.45)$ & 0.981 \\
\hline Male infertility, n (\%) & 17 & $(54.84)$ & 11 & $(55.00)$ & 6 & $(54.55)$ & \\
\hline $\begin{array}{l}\text { Number of previous } \\
\text { IVF }\end{array}$ & 2.00 & $(1.00-3.00)$ & 1.50 & $(1.00-2.75)$ & 2.00 & $(1.00-3.00)$ & 0.660 \\
\hline $\begin{array}{l}\text { Serum estradiol } \\
(\mathrm{pmol} / \mathrm{l})\end{array}$ & 1504.50 & $\begin{array}{l}(932.75- \\
3063.25)\end{array}$ & 1569.50 .75 & $\begin{array}{l}(848.75- \\
5353)\end{array}$ & 1504.50 & $\begin{array}{l}(1233.25- \\
2489.50)\end{array}$ & 0.930 \\
\hline $\begin{array}{l}\text { Serum progesterone } \\
(\mathrm{pmol} / \mathrm{l})\end{array}$ & 39.00 & $\begin{array}{l}(27.05- \\
60.55)\end{array}$ & 37.80 & $\begin{array}{l}(25.50- \\
62.80)\end{array}$ & 40.30 & $\begin{array}{l}(25.5975- \\
49.325)\end{array}$ & 0.854 \\
\hline Serum_LH (IU) & 3.40 & $(2.40-4.90)$ & 3.20 & $(2.30-4.10)$ & 4.30 & $(2.65-5.93)$ & 0.291 \\
\hline $\begin{array}{l}\text { Dose of FSH } \\
\text { stimulation (IU) }\end{array}$ & 1500.00 & $\begin{array}{l}(1125.00- \\
2250.00)\end{array}$ & 1500.00 & $\begin{array}{l}(1162.50- \\
2268.75)\end{array}$ & 1500.00 & $\begin{array}{l}(1125.00- \\
2250.00)\end{array}$ & 0.836 \\
\hline Retrieved oocytes & 6.00 & $(4.00-11.00)$ & 6.00 & $(4.00-9.75)$ & 11.00 & $(5.00-13.00)$ & 0.164 \\
\hline $\begin{array}{l}\text { Duration of } \\
\text { stimulation days }\end{array}$ & 8.16 & $(4.00-11.00)$ & 6.00 & $(4.00-9.75)$ & 9.45 & $(5.00-13.00)$ & 0.266 \\
\hline Matured oocytes & 5.00 & $(3.00-11.00)$ & 5.00 & $(3.00-8.00)$ & 7.00 & $(4.00-11.00)$ & 0.406 \\
\hline $\begin{array}{l}\text { Viable (Grade 1) } \\
\text { embryo }\end{array}$ & 3.00 & $(2.00-5.00)$ & 2.00 & $(2.00-4.75)$ & 5.00 & $(2.50-8.50)$ & 0.373 \\
\hline Transferred embryo & 2.00 & $(1.00-2.00)$ & 2.00 & $(1.00-2.00)$ & 5.00 & $(2.50-8.50)$ & 0.768 \\
\hline $\begin{array}{l}\text { Serum HCG on day } \\
12 \text { (IU) }\end{array}$ & 2.82 & $\begin{array}{l}(0.14- \\
213.29)\end{array}$ & 0.93 & $(0.00-2.81)$ & 292.25 & $\begin{array}{l}(165.68- \\
869.39)\end{array}$ & 0.000 \\
\hline $\begin{array}{l}\text { Chemical pregnancy, } \\
\mathrm{n}(\%)\end{array}$ & & & & & 11 & $(35.5)$ & \\
\hline $\begin{array}{l}\text { Clinical pregnancy, } \mathrm{n} \\
(\%)\end{array}$ & & & & & 9 & $(29.0)$ & \\
\hline
\end{tabular}

\section{TABLE 2}

The mRNA of methyltransferases (DNMT1, DNMT3a, DNMT3b) and histone deacetylases (HDAC5, HDAC6) in granulosa cell and follicular fluid of patients who underwent IVF treatment (median, $25-75 \%$ percentiles mean \pm SD) 


\begin{tabular}{|c|c|c|c|c|c|c|c|c|c|c|}
\hline \multirow[b]{2}{*}{ All Patients } & \multicolumn{5}{|c|}{ Granulosa cell } & \multicolumn{5}{|c|}{ Follicular fluid } \\
\hline & DNMT1 & DNMT3A & DNMT3B & HDAC5 & HDAC6 & DNMT1 & DNMT3A & DNMT3B & HDAC5 & HDAC6 \\
\hline Median & .084858 & .069348 & .002063 & .025208 & .017579 & .139179 & .019664 & .003619 & .005273 & .040887 \\
\hline 75 & .159124 & .092783 & .007564 & .063372 & .039936 & .197568 & .028576 & .005962 & .008598 & .060114 \\
\hline 25 & .011298 & .027584 & .000225 & .010672 & .012791 & .039190 & .012021 & .002387 & .003768 & .025210 \\
\hline \multicolumn{11}{|c|}{$\begin{array}{l}\text { Pregnancy-negative } \\
\text { patients }\end{array}$} \\
\hline Median & .074325 & .064238 & .001760 & .018808 & .015625 & .166663 & .014579 & .003619 & .006092 & .040887 \\
\hline 75 & .144128 & .105109 & .007139 & .060071 & .033843 & .203121 & .021344 & .006479 & .008431 & .055943 \\
\hline 25 & .022484 & .032191 & .000103 & .007531 & .011373 & .019114 & .009486 & .002577 & .003652 & .030561 \\
\hline \multicolumn{11}{|c|}{$\begin{array}{l}\text { Pregnancy-positive } \\
\text { patients }\end{array}$} \\
\hline Median & .108067 & .077482 & .003285 & .044811 & .032270 & .091807 & $.029157 *$ & .003709 & .005140 & .042078 \\
\hline 75 & .220554 & .094753 & .007867 & .083161 & .056820 & .183855 & .058244 & .005393 & .010638 & .316315 \\
\hline 25 & .010421 & .009623 & .000679 & .020460 & .017042 & .037638 & .023539 & .000895 & .003550 & .013827 \\
\hline
\end{tabular}

TABLE 3

Correlations between the mRNA expression of methyltransferases (DNMT1, DNMT3a, DNMT3b) and histone deacetylases (HDAC5, HDAC6) in granulosa cells and follicular fluid of patients who underwent IVF treatment. 


\begin{tabular}{|c|c|c|c|c|c|c|c|c|c|c|c|c|}
\hline & & & \multicolumn{5}{|c|}{ Granulosa cell } & \multicolumn{5}{|c|}{ Follicular fluid } \\
\hline & & & DNMT1 & DNMT3A & DNMT3B & HDAC5 & HDAC6 & DNMT1 & DNMT3A & DNMT3B & HDAC5 & HDAC6 \\
\hline & DNMT1 & $\mathrm{R}$ & 1.000 & .179 & .422 & .255 & .003 & .103 & -.033 & -.164 & -.144 & -.430 \\
\hline & & $p$ & & .345 & $.028^{*}$ & .174 & .989 & .658 & .892 & .490 & .535 & .052 \\
\hline \multirow[t]{2}{*}{ cell } & DNMT3A & $\mathrm{R}$ & .179 & 1.000 & .095 & .196 & .195 & .280 & .478 & .333 & .184 & -.098 \\
\hline & & $\mathrm{p}$ & .345 & & .632 & .292 & .311 & .208 & $.033^{\star}$ & .140 & .412 & .665 \\
\hline \multirow[t]{10}{*}{ Granulosa } & DNMT3B & $\mathrm{R}$ & .422 & .095 & 1.000 & .495 & .289 & .033 & -.176 & .005 & .196 & -.108 \\
\hline & & $\mathrm{p}$ & $.028^{*}$ & .632 & & $.007 *$ & .144 & .890 & .484 & .983 & .409 & .650 \\
\hline & HDAC5 & $\mathrm{R}$ & .255 & .196 & .495 & 1.000 & .683 & -.151 & .009 & .003 & .175 & -.033 \\
\hline & & $\mathrm{p}$ & .174 & .292 & $.007 * \star$ & & $.001 * \star$ & .503 & .970 & .991 & .436 & .883 \\
\hline & HDAC6 & $\mathrm{R}$ & .003 & .195 & .289 & .683 & 1.000 & -.330 & -.060 & -.343 & -.214 & -.075 \\
\hline & & $\mathrm{p}$ & .989 & .311 & .144 & $.001^{\star \star}$ & & .144 & .808 & .139 & .352 & .746 \\
\hline & DNMT1 & $\mathrm{R}$ & .103 & .280 & .033 & -.151 & -.330 & 1.000 & .451 & .045 & .190 & .149 \\
\hline & & $p$ & .658 & .208 & .890 & .503 & .144 & & $.046^{*}$ & $.034^{\star}$ & .396 & .510 \\
\hline & DNMT3A & $\mathrm{R}$ & -.033 & .478 & -.176 & .009 & -.060 & .451 & 1.000 & .256 & .150 & .060 \\
\hline & & $\mathrm{p}$ & .892 & $.033^{*}$ & .484 & .970 & .808 & $.046^{\star}$ & & .290 & .527 & .801 \\
\hline \multirow[t]{2}{*}{ fluid } & DNMT3B & $\mathrm{R}$ & -.164 & .333 & .005 & .003 & -.343 & .465 & .025 & 1.000 & .614 & .452 \\
\hline & & $\mathrm{p}$ & .490 & .140 & .983 & .991 & .139 & $.034 *$ & .290 & & $.003^{\star \star}$ & $.040 *$ \\
\hline \multirow[t]{4}{*}{ Follicular } & HDAC5 & $\mathrm{R}$ & -.144 & .184 & .196 & .175 & -.214 & .190 & .150 & .614 & 1.000 & .453 \\
\hline & & $\mathrm{p}$ & .535 & .412 & .409 & .436 & .352 & .396 & .527 & $.003^{\star \star}$ & & $.034^{\star}$ \\
\hline & HDAC6 & $\mathrm{R}$ & -.430 & -.098 & -.108 & -.033 & -.075 & .149 & .060 & .452 & .453 & 1.000 \\
\hline & & $\mathrm{p}$ & .052 & .665 & .650 & .883 & .746 & .510 & .801 & $.040 *$ & $.034^{\star}$ & \\
\hline
\end{tabular}

